\title{
sciendo
}

Int. J. of Applied Mechanics and Engineering, 2021, vol.26, No.3, pp.28-43

DOI: 10.2478/ijame-2021-0033

\section{COMPARING PERFORMANCE OF CROSS-LAMINATED TIMBER AND REINFORCED CONCRETE WALLS}

\author{
A.BAHRAMI*, O.NEXÉN and J.JONSSON \\ Department of Building Engineering, Energy Systems and Sustainability Science, Faculty of Engineering \\ and Sustainable Development, University of Gävle, 80176 Gävle, SWEDEN \\ E-mail: Alireza.Bahrami@hig.se
}

\begin{abstract}
The purpose of this research is to specify the differences between the performance of cross-laminated timber (CLT) and reinforced concrete (RC) walls. The study is done by using the finite element structural analysis and design software, StruSoft FEM-Design, in order to model, analyse and design a reference building located in the city of Gävle in Sweden. The building is firstly modelled, analysed and designed using RC walls and then the RC walls are replaced with CLT walls. In both buildings, other load-bearing elements such as slabs, beams and columns are made of RC while the roof beams are made of glulam. It is found that employing RC has advantages, especially regarding thickness. The results show that the CLT walls require larger dimensions than their RC counterparts. Meanwhile, it is demonstrated that the slabs, beams and columns made of RC in the building having the CLT walls require more reinforcement or larger thickness than the case of walls made of RC. Moreover, the total weight of the building having the CLT walls is $74 \%$ of the building having the RC walls. The lower weight of the building having the CLT walls has great advantages such as having lighter foundation and being cost-effective and also beneficial for the environment.
\end{abstract}

Key words: cross-laminated timber wall, reinforced concrete wall, load-bearing, finite element method, utilisation ratio.

\section{Introduction}

Today's climate change affects all countries around the world. The weather is getting more extreme, water levels are higher, and greenhouse gas emissions are higher than ever. To combat the climate change, most of the countries of the world have jointly signed the Paris Agreement. Together, the countries must individually strive for a reduced climate impact with the common goal of slowing down the climate change. The construction sector accounts for a large part of the world's environmental impact, but there is a good potential for the improvement.

Concrete is the most common and traditional building material for multi-storey buildings today and requires a lot of energy to produce. It also accounts for a large part of the greenhouse gas emissions during the production phase. Cross-laminated timber (CLT) has become very popular choice of material for timber bearing structures [1]. CLT is a product that is extremely suitable for multi-storey buildings thanks to its versatility [2]. Although the environmental impact is less for wood than concrete, concrete is still the dominant material to build multi-storey buildings, the reason why CLT is not used to a greater extent can partly be because the knowledge of the material is not as detailed as for concrete and also because both experience and detailed recommendations for high-rise multi-storey buildings in wood are almost missing.

Some researchers have examined CLT walls [3-14]. However, this paper compares the structural performance of CLT and reinforced concrete (RC) walls. The StruSoft FEM-Design (FEM-Design) software is used to model, analyse and design a reference building located in the city of Gävle in Sweden. The building is modelled, analysed and designed using RC walls and then the RC walls are replaced with the CLT walls. Other load-bearing elements as slabs, beams and columns are made of $\mathrm{RC}$ while the roof beams are made of glulam in

\footnotetext{
* To whom correspondence should be addressed
} 
both buildings. The results obtained for both buildings are compared and discussed in terms of their utilisation ratio and weight.

\section{Method}

The methodology of the research is represented herein. The features of the buildings and the numerical study are explained below.

\subsection{Features of buildings}

In this research, an existing building was used as a starting point. The building is located in the city of Gävle in Sweden and was built in 2018. The building is a 4-storey residential house, plus one entrance storey and one basement, with the dimensions of $29.3 \mathrm{~m}$ in length and $13.3 \mathrm{~m}$ in width which has an RC frame. Figures 1-6 illustrate the floor plans of the building. In the plans, the walls of the building were named as IV or YV which respectively stand for interior walls or exterior walls.

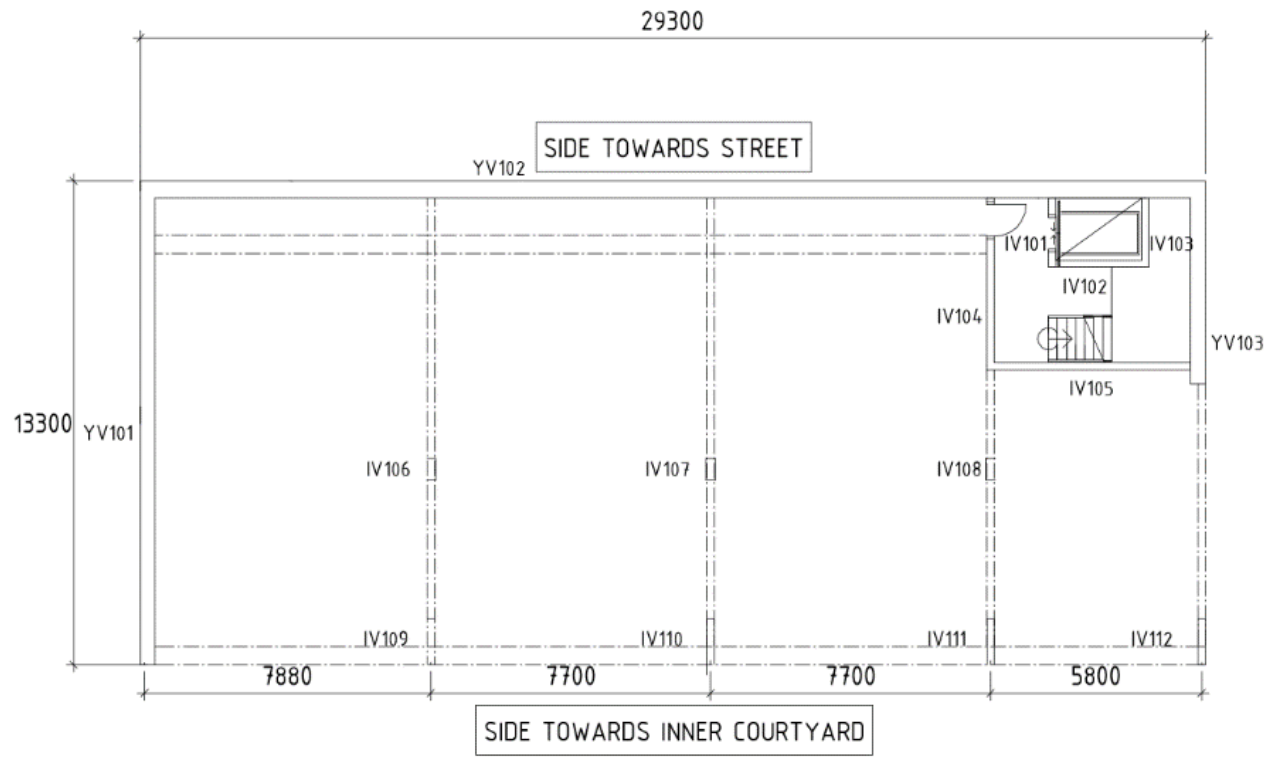

Fig.1. Basement (dimensions are in $\mathrm{mm}$ ).

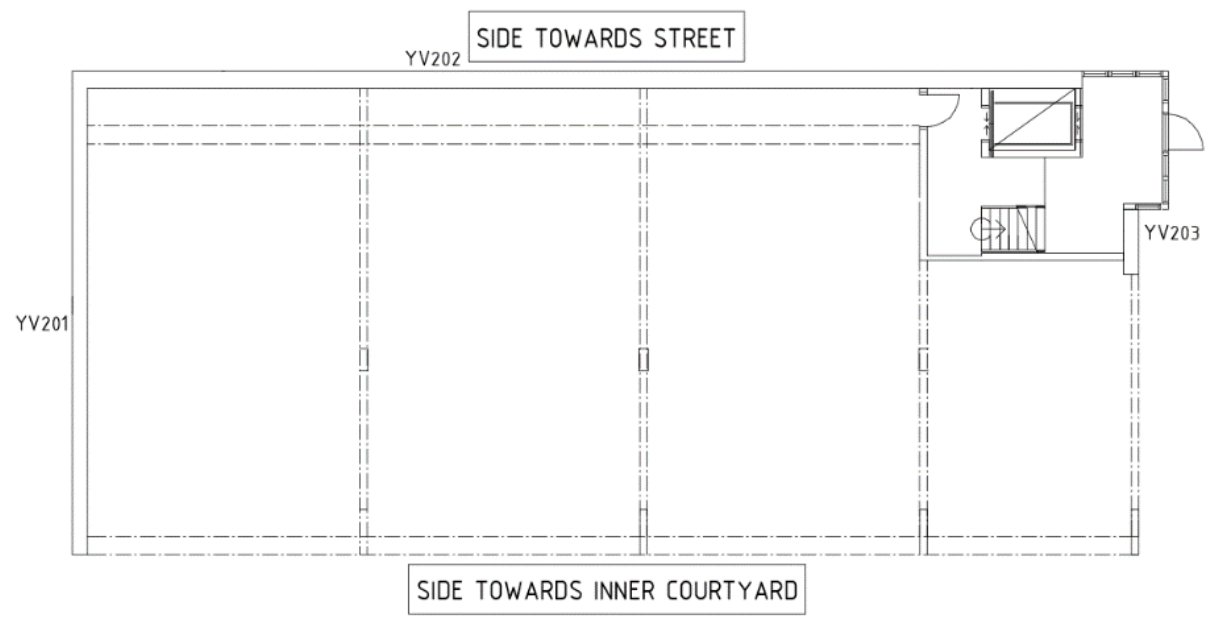

Fig.2. Entrance floor. 
In the building, all floors and exterior and interior walls are $200 \mathrm{~mm}$ thick. The storey height is $3.3 \mathrm{~m}$ from floor to floor in all the storeys except in the basement where the height is $3 m$. Balconies are on both long sides, one is facing a courtyard and is on storeys $2-4$, as storey 1 on this side is at the ground level. These are $2 m$ wide and are supported by columns. The balconies on the other side are facing a passage to each apartment's entrance. These are $1.4 m$ wide and free-hanging, except for the balcony in the first storey which is supported by a wall.

The roof of the building is a mono-pitch roof with a 7-degree slope. Based on the drawings, anything that was not structurally relevant was removed from the plans such as kitchens and non-load bearing walls.

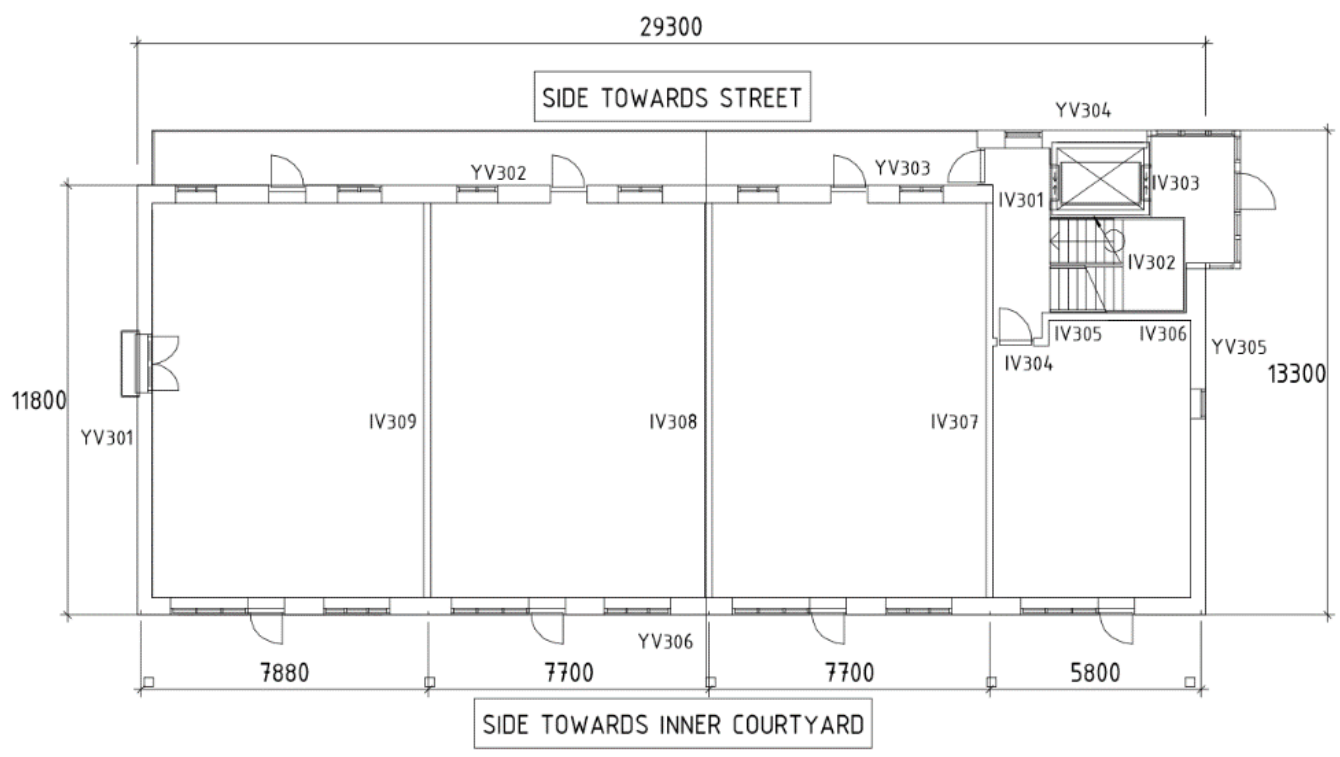

Fig.3. Floor 1 (dimensions are in $\mathrm{mm}$ ).

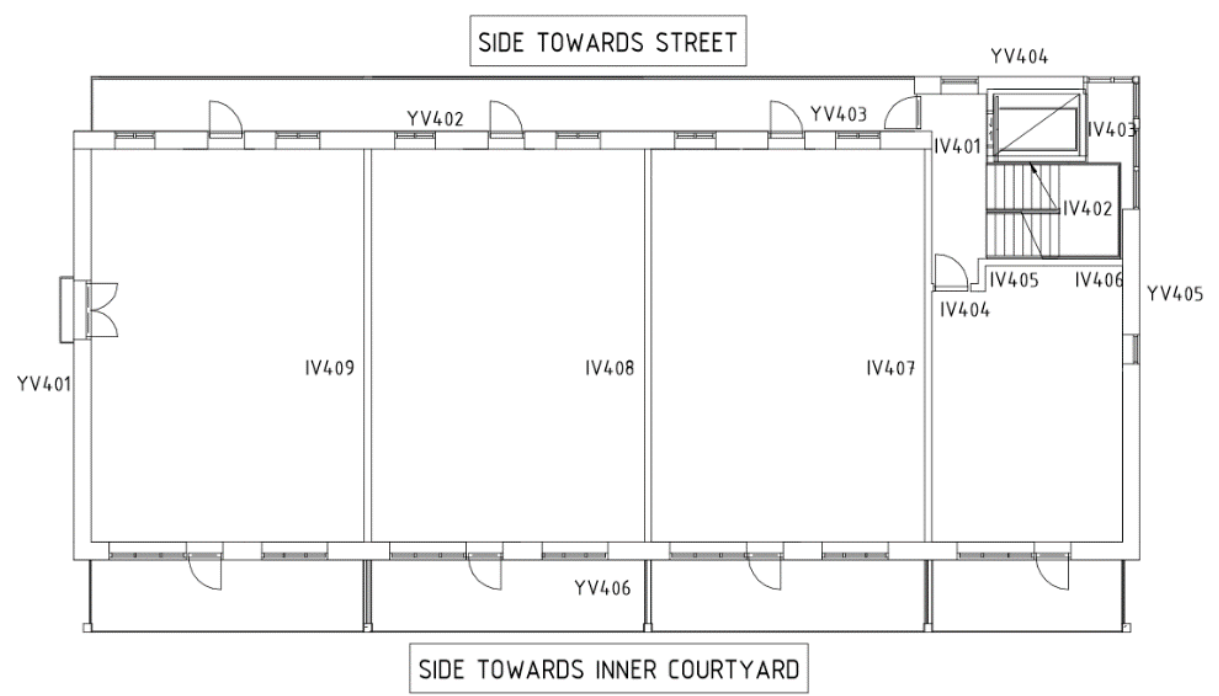

Fig.4. Floor 2.

\subsection{Numerical study}

The numerical study includes the loads and modelling the buildings using the FEM-Design software which are presented. 


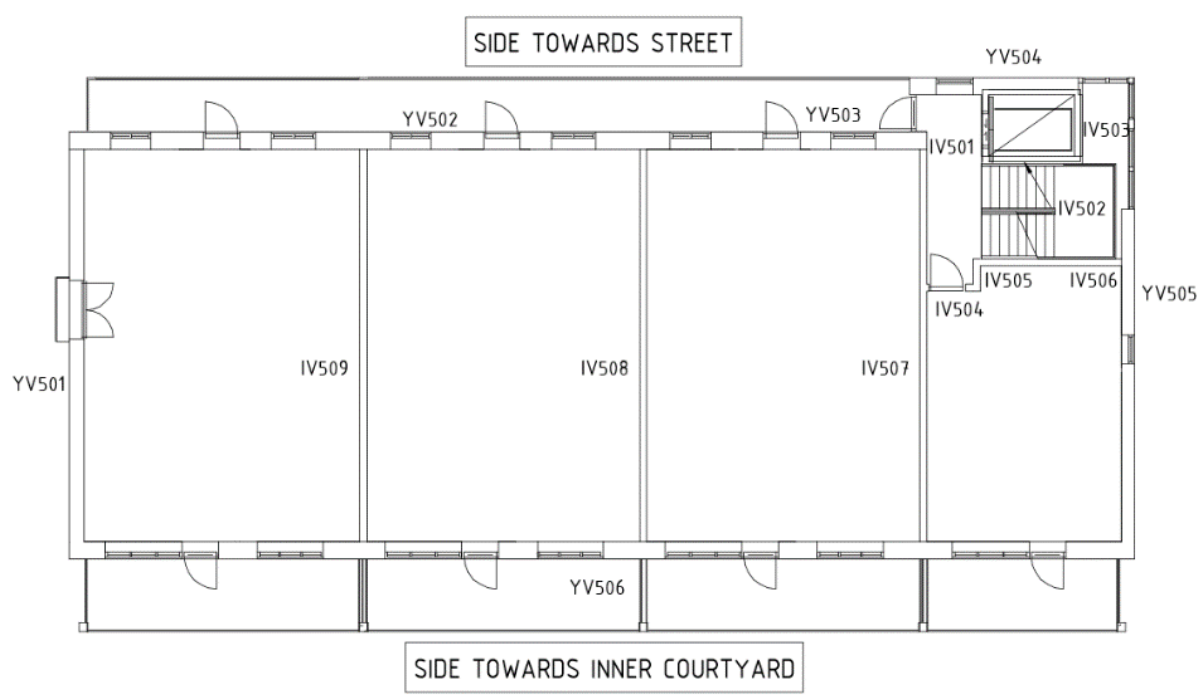

Fig.5. Floor 3.

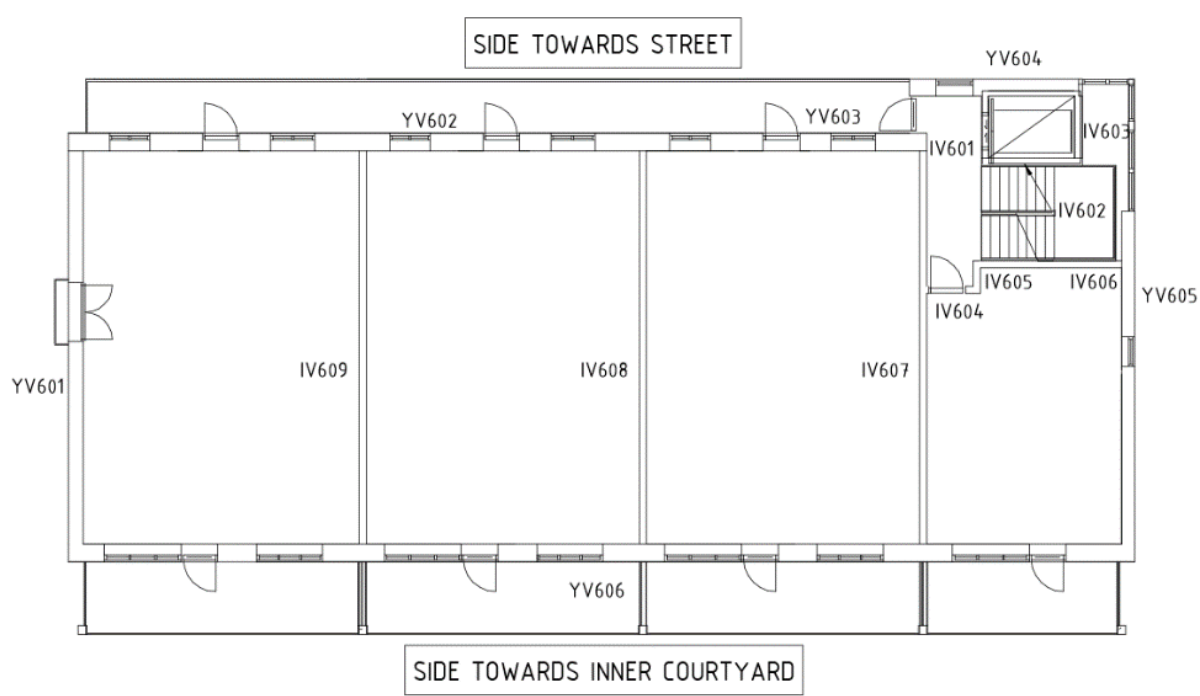

Fig.6. Floor 4.

\subsubsection{Loads}

Before the analysis and design of the load-bearing elements of the building were begun, its current load cases were considered. With a given usage function, floor height and location, the current loads for the building could be defined with the help of the guidelines reported in the Eurocode and Swedish national annex (EKS). Table 1 lists the loads accounted for the building. According to the code, the building is in a snow zone of $2.5 \mathrm{kN} / \mathrm{m}^{2}$, however, the snow load was calculated with employing a form factor, exposure factor and thermal coefficient based on the code. The building has a reference wind speed of $23 \mathrm{~m} / \mathrm{s}$. As the building is close to the sea but is not fully exposed to the sea, terrain type I was taken into account to be the most relevant terrain type for the building. The wind load was then calculated applying the reference wind speed. Self-weight, excluding the self-weight of the load-bearing elements which the software can consider, was chosen to be $0.5 \mathrm{kN} / \mathrm{m}^{2}$ for all the floors located inside the exterior walls. Balconies and attic corridors did not have any extra weights, as there is only RC. The weight of $0.5 \mathrm{kN} / \mathrm{m}^{2}$ was adopted due to the fact that the insulation and wooden 
floors are placed there and they were expected together to result in the specified weight. The self-weight of the building on the roof was chosen $0.8 \mathrm{kN} / \mathrm{m}^{2}$.

The building is a residential building and its imposed load was adopted according to the code as $2.0 \mathrm{kN} / \mathrm{m}^{2}$ for the indoor floors. The non-load bearing interior walls gave an extra load of $0.8 \mathrm{kN} / \mathrm{m}^{2}$ to the imposed load. As a result, the total imposed load for the floors was set at $2.8 \mathrm{kN} / \mathrm{m}^{2}$. The imposed load for all the balconies was taken as $3.5 \mathrm{kN} / \mathrm{m}^{2}$ following the code. The roof was only expected to be visited for maintenance and thus an imposed load of $0.5 \mathrm{kN} / \mathrm{m}^{2}$ was chosen for that purpose. The imposed load for the basement was considered $2.5 \mathrm{kN} / \mathrm{m}^{2}$ because the parking garage was intended for passenger cars.

Table 1. Loads.

\begin{tabular}{|l|c|}
\hline \multicolumn{1}{|c|}{ Type of load } & Considerations for load \\
\hline Self-weight of floor & $0.5 \mathrm{kN} / \mathrm{m}^{2}+$ self-weight \\
\hline Self-weight of roof & $0.8 \mathrm{kN} / \mathrm{m}^{2}+$ self-weight \\
\hline Imposed load of floor & $2.8 \mathrm{kN} / \mathrm{m}^{2}$ \\
\hline Imposed load of balcony & $3.5 \mathrm{kN} / \mathrm{m}^{2}$ \\
\hline Imposed load of roof & $0.5 \mathrm{kN} / \mathrm{m}^{2}$ \\
\hline Imposed load of parking & $2.5 \mathrm{kN} / \mathrm{m}^{2}$ \\
\hline Snow load & $2.5 \mathrm{kN} / \mathrm{m}^{2}$ (zone load) \\
\hline Wind load & $23 \mathrm{~m} / \mathrm{s}$ (reference wind speed) \\
\hline
\end{tabular}

\subsubsection{Modelling buildings using FEM-Design software}

FEM-Design software is a powerful three-dimensional (3D) finite element computer program with which it can be possible to analyse and design structures according to the Eurocode and EKS. To accurately analyse and design the building, modelling should be done correctly and input data should exactly be considered. A description of the method for modelling, analysing and designing the buildings in the FEMDesign software is given below.

All RC elements were selected with the concrete compressive strength class of C30/37 and they were also made as fixed at supports. Roof beams were glulam with the strength class of GL30c and their supports were hinged. Point and line supports were utilised to place the supports for the elements. They were the supports for the elements that rested on the specified material or location and were selected depending on whether they were a line load or a point load that acted against the support. For example, point support was used for all columns whose support was against the ground and line support was employed for all walls whose support was against the ground. Their properties were also selected based on whether the supports received moment, normal force or horizontal force. As mentioned for RC, the supports were chosen as fixed since RC walls and columns were assumed to be fixed. When all the building elements were modelled, modelling was proceeded to define the loads that were expected to affect the building. The loads reported in Table 1 were considered for the modelled building. Load groups and load combinations were applied to generate different load cases. The load combinations compiled all possible load situations that may occur in the building according to the load groups that had been introduced. When all the loads were defined and placed in their specified locations with their specified values, modelling then progressed to analyse and design the building elements. Once the building was modelled, analysed and designed using RC walls, another time RC walls were replaced with CLT walls. Thus, two buildings were modelled, analysed and designed. The largest size of CLT manufactured by Södra is CLT $280 \mathrm{~L} 7 \mathrm{~s}$, which means a board of CLT that is $280 \mathrm{~mm}$ thick consisting of 7 layers of boards. In two cases of the CLT walls, utilisation ratio below $100 \%$ could not be obtained with the largest size of CLT. Therefore, the floor plan was supplemented with two additional walls to achieve utilisation ratio below $100 \%$. Figures $7-9$ demonstrate what the building looks like in the software. The figures show different views of the modelled building including the openings, roof design and placement of all the loadbearing elements of the building. In Figure 7, the green line displays the ground level of the building. 


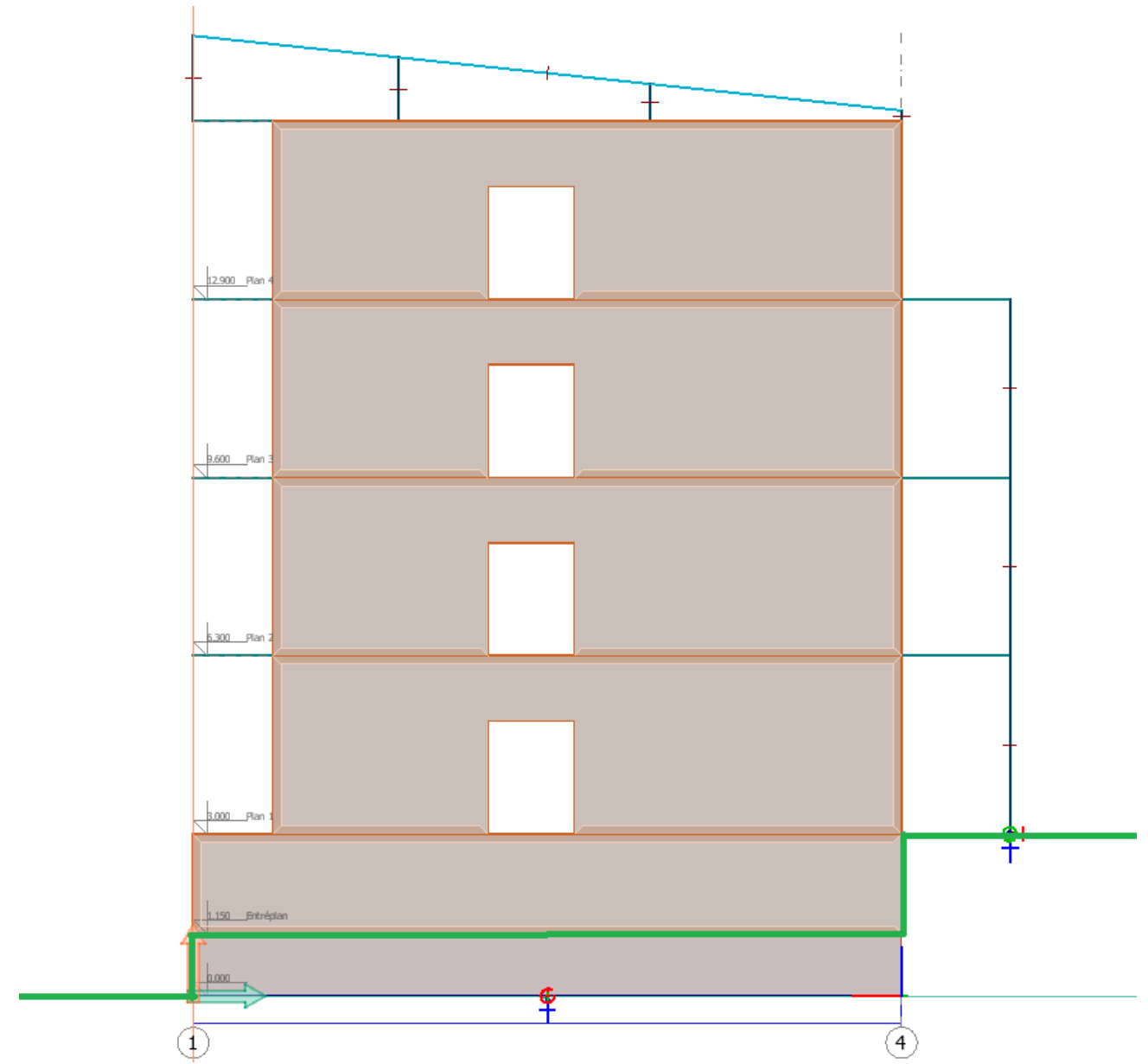

Fig.7. Elevation view of the short side.

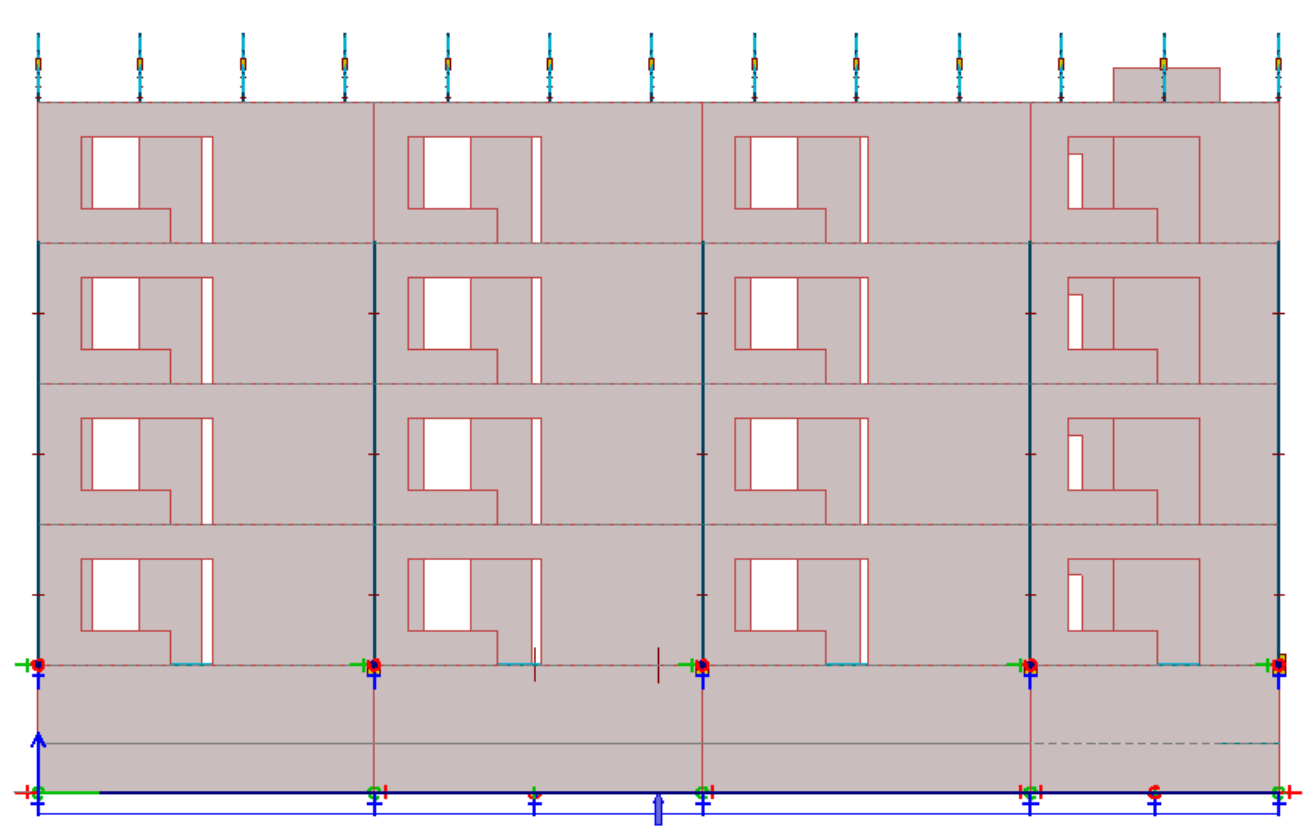

Fig.8. Elevation view of the long side, seen from the courtyard. 


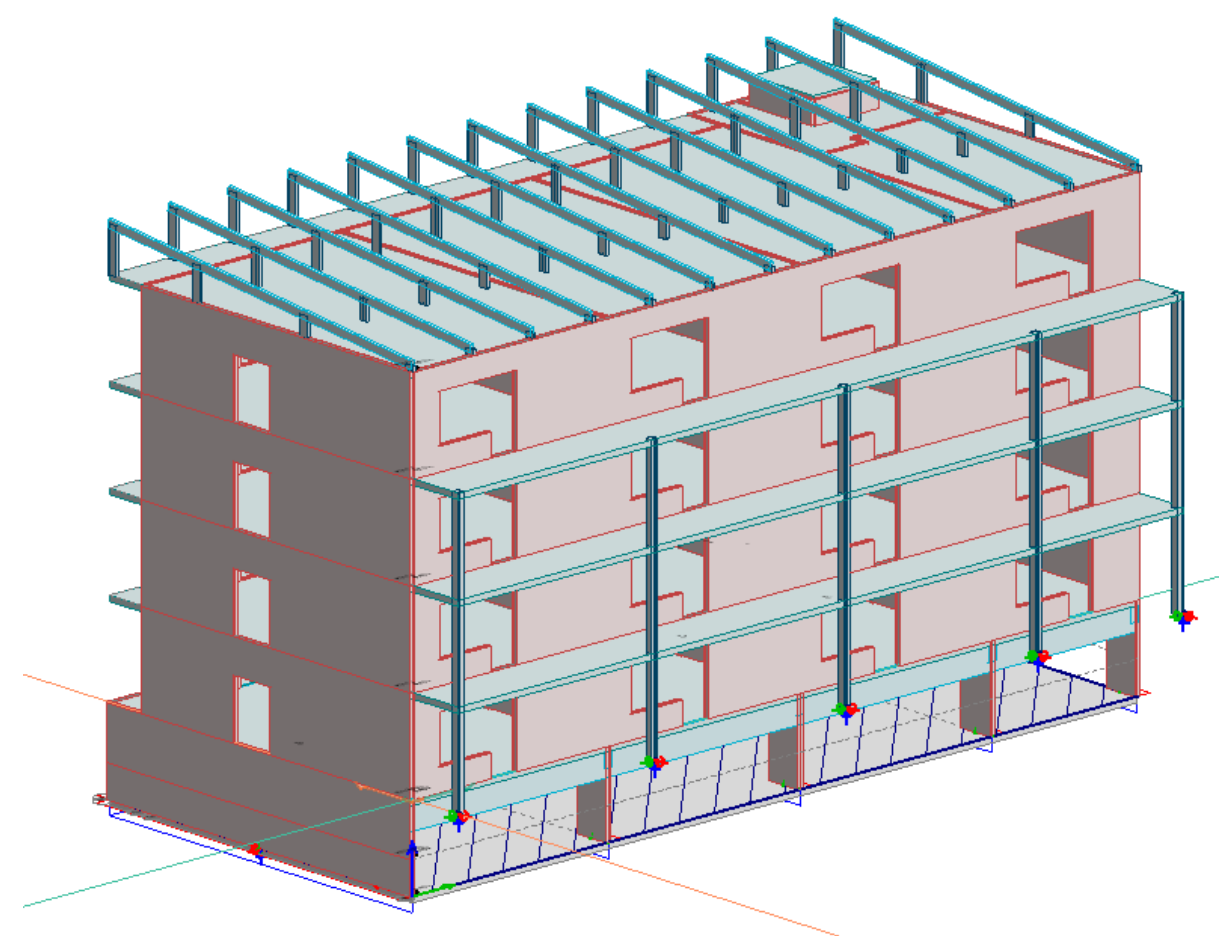

Fig.9. 3D view of the building, seen from the courtyard.

\section{Results and discussions}

This section provides the results for the load-bearing elements of the buildings having RC and CLT walls that were analysed and designed by the use of the FEM-Design software. In sections 3.1 and 3.2, the results are reported based on the utilisation ratio and weight in tables. All walls and slabs which were made of RC had a thickness of $200 \mathrm{~mm}$, except for the slab in floor 1 where the walls were made of CLT whose thickness was $250 \mathrm{~mm}$. All the RC elements were considered in the strength class of C30/37. The CLT modules were from the Södra type. All the analysed and designed elements of the buildings achieved an acceptable deflection within the specified limiting value based on the code. In section 3.3, the obtained results are compared and discussed, too.

\subsection{Building having $\mathrm{RC}$ walls}

The modelled building having walls, slabs, beams and columns made of RC was analysed and designed. The beams of the roof were made of glulam which were also analysed and designed. Table 2 summarises the results for those $\mathrm{RC}$ walls that had the highest utilisation ratio in each storey. Also, the results for some of the RC slabs are reported in Table 3. Moreover, Table 4 presents the weight of the building having the RC walls.

Table 2. Results for RC walls.

\begin{tabular}{|c|c|c|}
\hline Designation & Utilisation ratio (\%) & Weight $(t)$ \\
\hline IV101 & 82 & 2.1 \\
\hline YV201 & 61 & 12.4 \\
\hline YV302 & 91 & 30 \\
\hline IV404 & 85 & 2 \\
\hline IV504 & 90 & 2 \\
\hline YV606 & 89 & 37.4 \\
\hline
\end{tabular}


Figure 10 indicates the utilisation ratios of the $\mathrm{RC}$ walls of the building in a colour palette which demonstrates that they have acceptable utilisation ratios. The utilisation ratios would be increased as the dark green parts became lighter, but the fact that they were obtained green means they had good utilisation ratios and the design of the $\mathrm{RC}$ walls of the building was carried out safely.

Table 3. Results for RC slabs of the building having RC walls.

\begin{tabular}{|l|c|c|}
\hline \multicolumn{1}{|c|}{ Slab } & Utilisation ratio (\%) & Weight $(t)$ \\
\hline Basement & 71 & 189.2 \\
\hline Entrance floor & 73 & 3.6 \\
\hline Floor 1 & 81 & 166.1 \\
\hline Floor 2 & 74 & 163.6 \\
\hline Floor 3 & 80 & 165.5 \\
\hline Floor 4 & 83 & 165.5 \\
\hline Roof & 64 & 193.9 \\
\hline
\end{tabular}

Table 4. Results for weight of the building having RC walls.

\begin{tabular}{|l|c|c|c|}
\hline \multicolumn{1}{|c|}{ Plan } & $\begin{array}{l}\text { Weight of walls } \\
\text { per floor }(t)\end{array}$ & $\begin{array}{l}\text { Weight of slabs, beams } \\
\text { and columns per floor }(t)\end{array}$ & $\begin{array}{l}\text { Total weight of walls, slabs, } \\
\text { beams and columns per floor }(t)\end{array}$ \\
\hline Basement & 58.7 & 248.3 & 307 \\
\hline Entrance floor & 39.8 & 3.6 & 43.4 \\
\hline Floor 1 & 178.2 & 185.7 & 363.9 \\
\hline Floor 2 & 176.3 & 212.2 & 388.5 \\
\hline Floor 3 & 177.3 & 212.2 & 389.5 \\
\hline Floor 4 & 155.4 & 212.5 & 367.9 \\
\hline Roof & 4.3 & 200.5 & 204.8 \\
\hline Total weight $(t)$ & 790 & 1275 & \\
\hline Total weight of building $(t)$ & \multicolumn{3}{|c|}{2065} \\
\hline
\end{tabular}

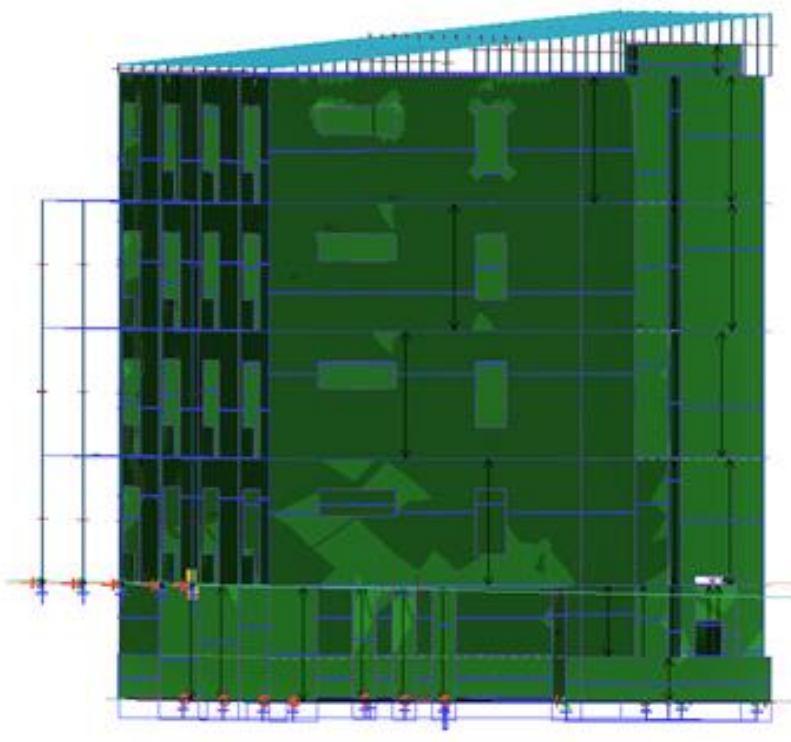

Fig.10. Utilisation ratios of RC walls of the building in colour palette. 


\subsection{Building having CLT walls}

Modelling, analysis and design of the building having CLT walls were performed similar to what was mentioned in section 3.1 for the building having the RC walls. The slabs, beams and columns of this building were also made of RC which were all modelled, analysed and designed. The roof beams were adopted as glulam. The results for the CLT walls that had the highest utilisation ratio in each storey are given in Table 5 .

Since the deflection of the RC slab in floor 1 was too large and the largest dimension of CLT was not sufficient to safely withstand the forces that the walls IV106 and IV107 were exposed to, two new CLT walls were added to the basement. These new walls were IV113 and IV114 which worked as a support for the slab and helped the walls IV106 and IV107. Figure 11 illustrates the locations of the new CLT walls and Table 6 gives their results.

Table 5. Results for CLT walls.

\begin{tabular}{|c|c|c|}
\hline Designation & Utilisation ratio (\%) & Weight $(t)$ \\
\hline IV106 & 72 & 0.2 \\
\hline YV201 & 26 & 2.8 \\
\hline IV309 & 42 & 2.3 \\
\hline IV404 & 37 & 0.2 \\
\hline IV504 & 36 & 0.2 \\
\hline IV604 & 35 & 0.2 \\
\hline
\end{tabular}

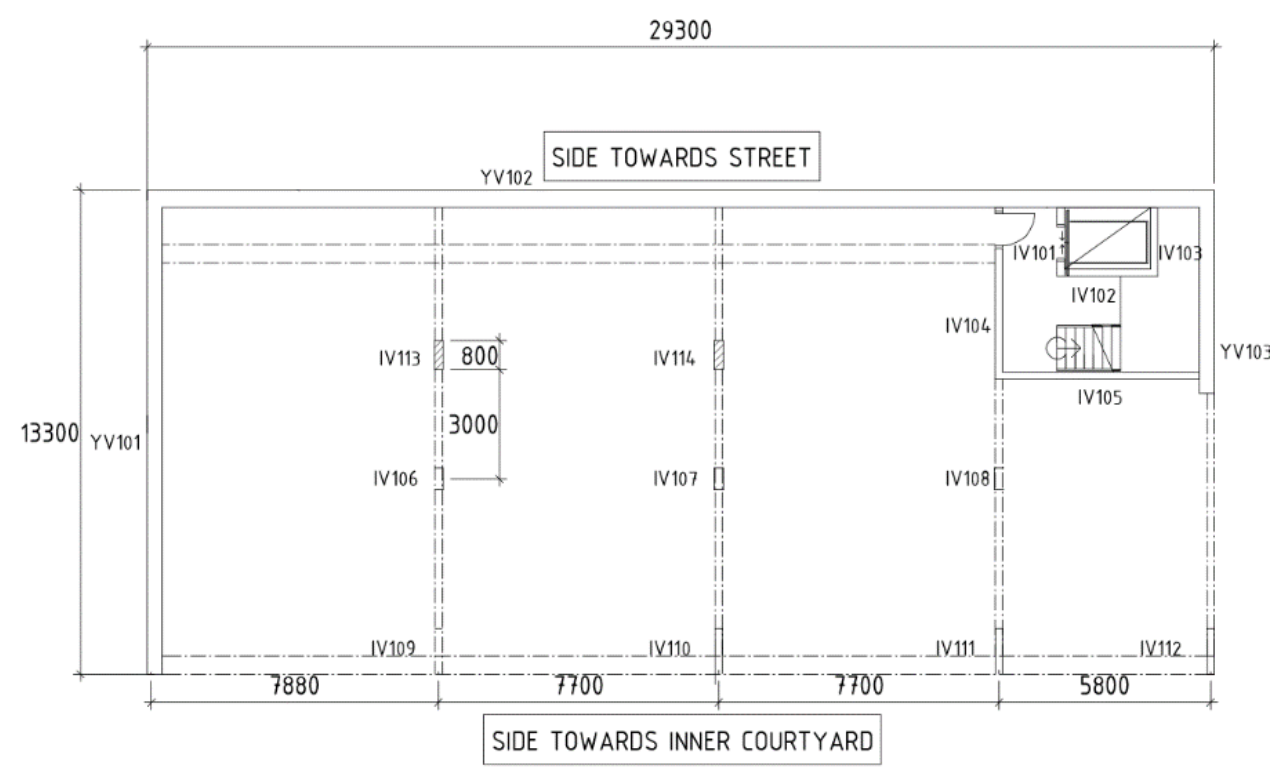

Fig.11. New plan for the basement due to adding two new CLT walls, IV113 and IV114 (dimensions are in $\mathrm{mm})$.

Table 6. Results for new CLT walls in the basement.

\begin{tabular}{|c|c|c|}
\hline Designation & Utilisation ratio (\%) & Weight $(t)$ \\
\hline IV113 & 80 & 0.3 \\
\hline IV114 & 77 & 0.3 \\
\hline
\end{tabular}


Meanwhile, the results for some of the RC slabs of the building having the CLT walls are listed in Table 7. In addition, the weights of the building having the CLT walls are reported in Table 8. Figure 12 depicts the utilisation ratios of the CLT walls of the building in a colour palette which reveals the acceptable utilisation ratios and safe design of the building.

Table 7. Results for RC slabs of the building having CLT walls.

\begin{tabular}{|l|c|c|}
\hline \multicolumn{1}{|c|}{ Slab } & Utilisation ratio (\%) & Weight $(t)$ \\
\hline Basement & 56 & 189.2 \\
\hline Entrance & 53 & 3.6 \\
\hline Floor 1 & 80 & 216.9 \\
\hline Floor 2 & 45 & 172.8 \\
\hline Floor 3 & 44 & 172.8 \\
\hline Floor 4 & 43 & 172.8 \\
\hline Roof & 54 & 198.6 \\
\hline
\end{tabular}

Table 8. Results for weight of the building having CLT walls.

\begin{tabular}{|l|c|c|c|}
\hline \multicolumn{1}{|c|}{ Plan } & $\begin{array}{l}\text { Weight of walls } \\
\text { per floor }(t)\end{array}$ & $\begin{array}{l}\text { Weight of slabs, beams } \\
\text { and columns per floor }(t)\end{array}$ & $\begin{array}{l}\text { Total weight of walls, slabs, } \\
\text { beams and columns per floor }(t)\end{array}$ \\
\hline Basement & 32.2 & 249.1 & 281.3 \\
\hline Entrance floor & 9.3 & 3.6 & 12.9 \\
\hline Floor 1 & 31.3 & 237.4 & 268.7 \\
\hline Floor 2 & 31.3 & 222.4 & 253.7 \\
\hline Floor 3 & 31.3 & 222.5 & 253.8 \\
\hline Floor 4 & 31.3 & 219.7 & 205.5 \\
\hline Roof & 0.3 & 205.2 & \\
\hline Total weight $(t)$ & 167 & 1359.9 & \\
\hline Total weight of building $(t)$ & \multicolumn{3}{|c|}{1526.9} \\
\hline
\end{tabular}

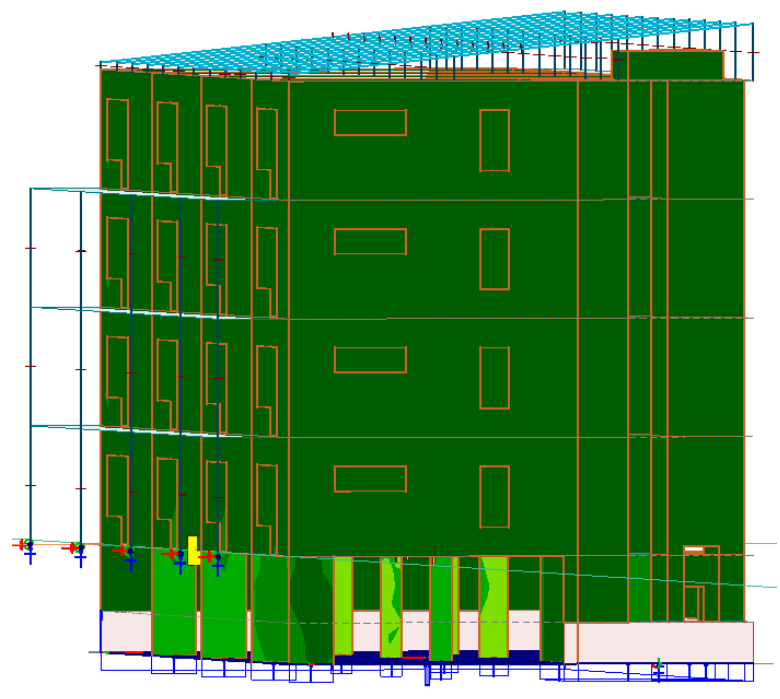

Fig.12. Utilisation ratios of CLT walls of the building in colour palette. 


\subsection{Comparison of results for buildings having RC and CLT walls}

This section presents comparisons of the results for buildings having the RC and CLT walls. The comparisons are made based on the utilisation ratio and weight. It is worth mentioning that the walls YV106 and YV107 in the building having the CLT walls which were supported by two additional walls, as mentioned in section 3.2, did not have the same conditions as the walls YV106 and YV107 in the building having the RC walls, this issue could also affect other load-bearing elements of the building from the basement to floor 1 .

\subsubsection{Comparison of utilisation ratios}

All the RC walls and slabs had a thickness of $200 \mathrm{~mm}$, except for the slab in floor 1 when the walls were made of CLT which required a thickness of $250 \mathrm{~mm}$. It was uncovered that the exterior CLT walls required larger thicknesses than the exterior RC walls in order to accomplish the acceptable utilisation ratio of less than $100 \%$.

Figures 13-18 display that the utilisation ratios were lower for CLT walls than RC walls in majority of the cases. In both buildings having the CLT and RC walls, the results for the walls were reflected in the results for the slabs, beams and columns made of RC. The RC slabs, beams and columns possessed greater amounts of reinforcement (in one case a thicker cross-section) and lower utilisation ratios when the walls were made of CLT. The reason why the slabs, beams and columns made of RC in the building having CLT walls required more reinforcement or larger thickness could be due to the point that the CLT walls did not act as rigid supports as the RC walls since their deflections were almost larger than the RC walls. It was also found that the RC slabs, which were set to be fixed, did not have the possibility of remaining fixed when the walls were no longer RC. As it was previously mentioned, when the CLT walls were used, some changes needed to be made to the RC elements of the building and two CLT walls had to be added.

The biggest problem for the CLT walls was their large deflections, in other words, all the CLT walls required an increased thickness despite their acceptable utilisation ratios. This was because the deflection was too large and an increased thickness became the answer to reduce the deflection to an acceptable level. On the other hand, the utilisation ratios finally achieved proved to be lower for the CLT walls than the RC walls and it was due to the fact that the deflections would be large if the CLT walls were to be designed regardless of the deflection. This means that the CLT walls could have significantly lower sizes if they were only designed based on the ultimate limit state but not the serviceability limit state. However, the buildings had to meet the requirements of both states.

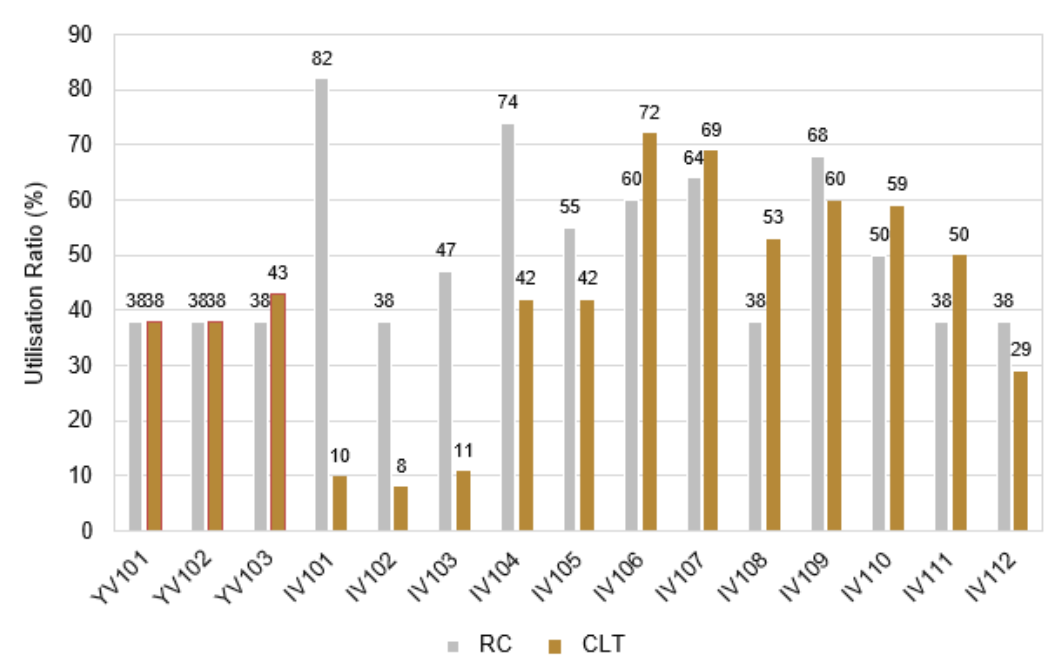

Fig.13. Comparison of utilisation ratios of RC and CLT walls in the basement. 


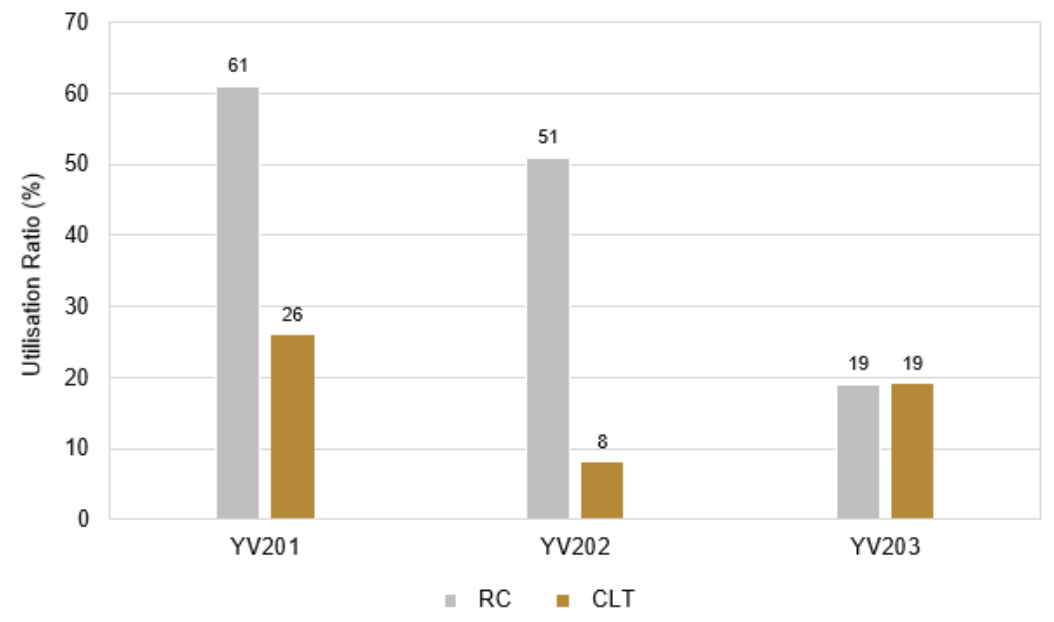

Fig.14. Comparison of utilisation ratios of RC and CLT walls in the entrance floor.

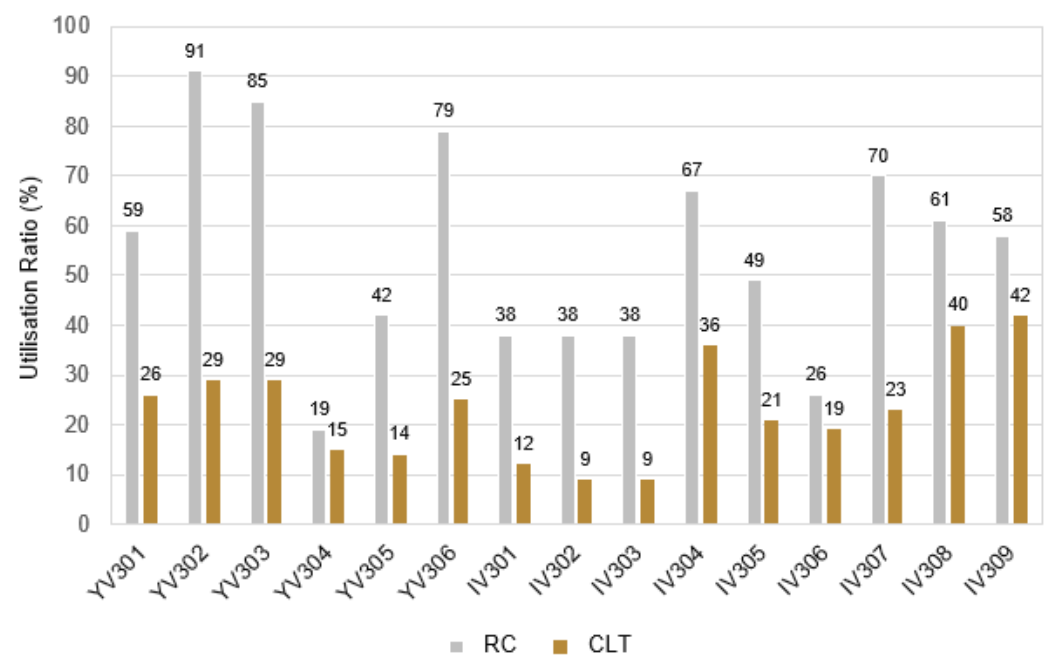

Fig.15. Comparison of utilisation ratios of RC and CLT walls in floor 1.

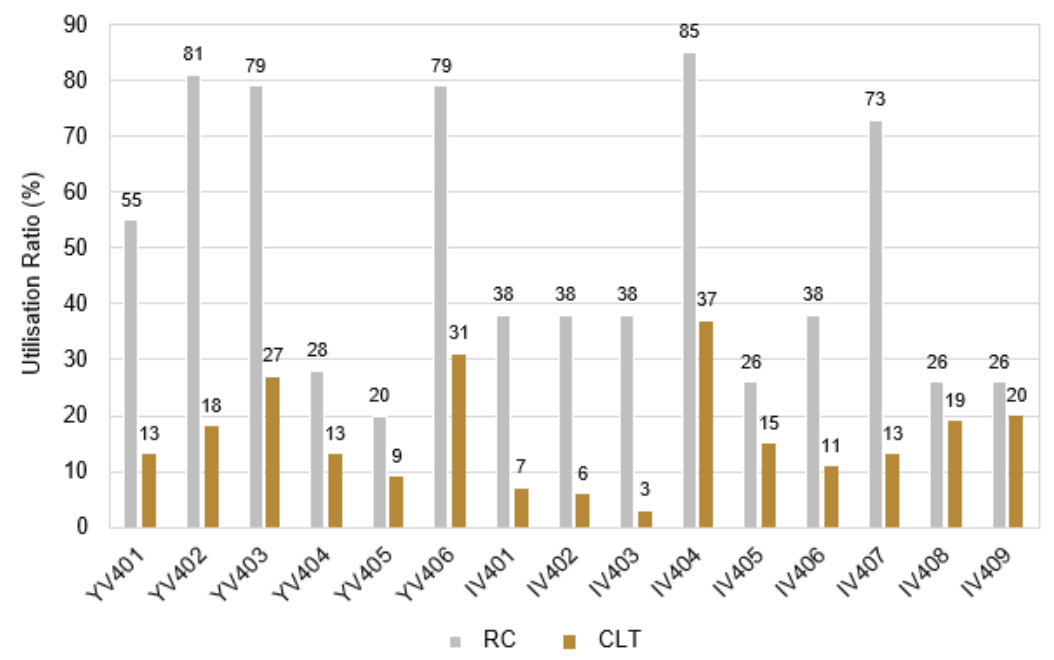

Fig.16. Comparison of utilisation ratios of RC and CLT walls in floor 2. 


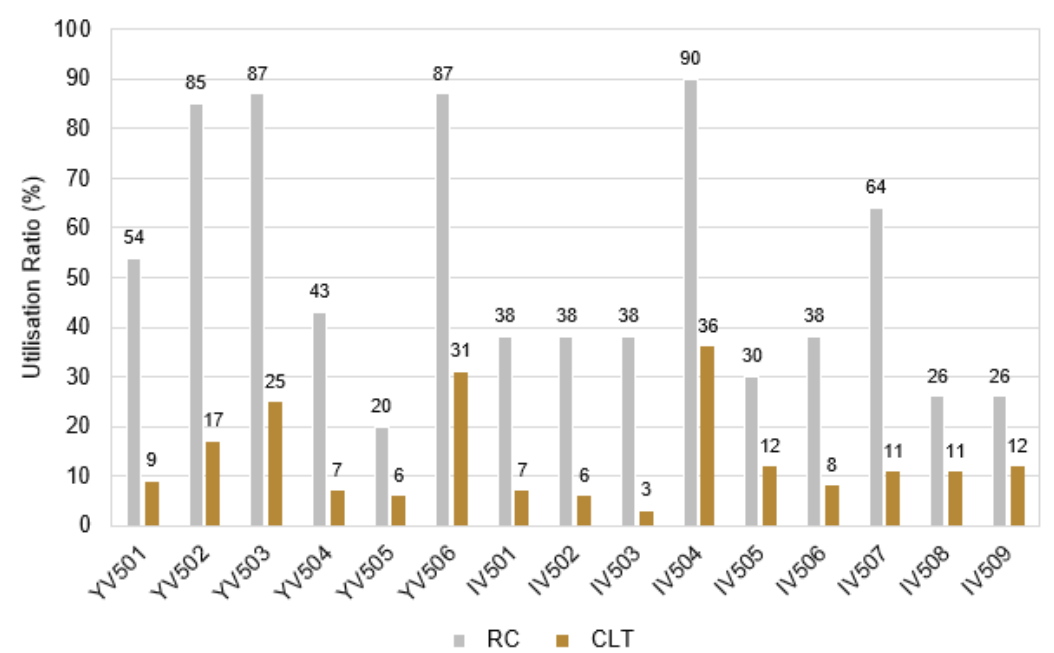

Fig.17. Comparison of utilisation ratios of RC and CLT walls in floor 3.

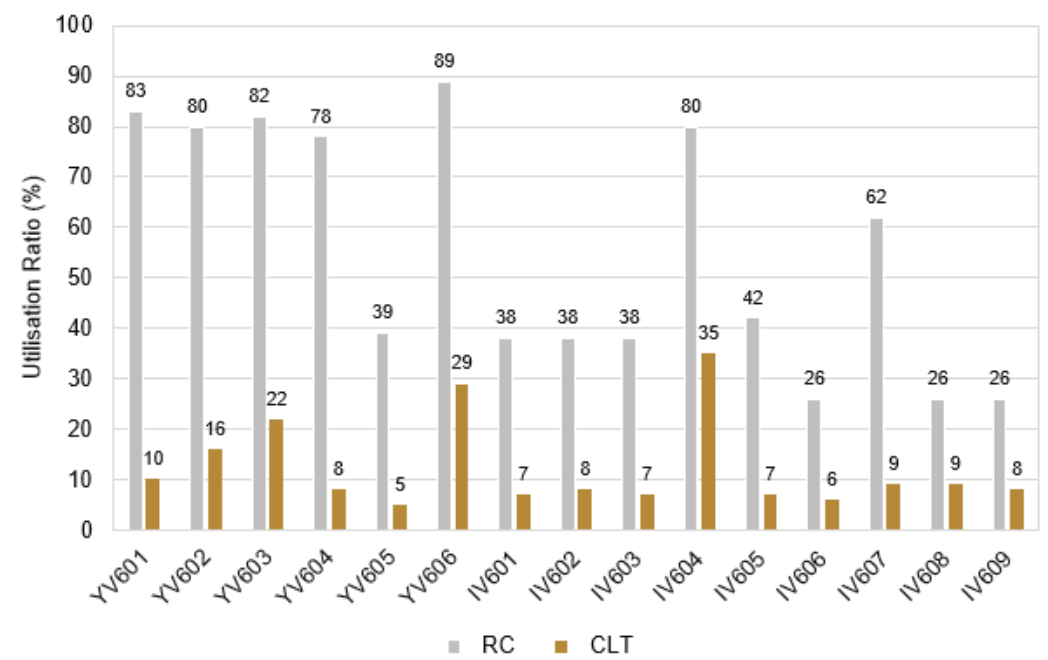

Fig.18. Comparison of utilisation ratios of RC and CLT walls in floor 4.

The RC walls, whose problems were largely the opposite of the CLT walls, only required an acceptable utilisation ratio since the deflection was not a problem with the $\mathrm{RC}$ walls. Consequently, most of the $\mathrm{RC}$ walls had the possibility of being thinner than the CLT walls, not because of the utilisation ratio, but thanks to the requirements for the deflection. As for the $\mathrm{RC}$ walls where the case was the opposite of the CLT walls, the ultimate limit state became the dominating state in their design and therefore the utilisation ratio and deflection were considerably different for the CLT and RC walls.

\subsubsection{Comparison of weights}

Different comparisons of weights are depicted in Figures 19-22. The total weight of the entire building having the CLT walls was 538.1t lower than the building having the RC walls, in other words, the total weight of the building having the CLT walls was only $74 \%$ of the building having the RC walls. However, based on the total weight of the walls, the difference between CLT and RC was $623 t$ signifying that the weight of the CLT walls only accounted for about $21 \%$ of the weight of the RC walls. This much lower weight of the CLT walls can lead to safer construction, easier lifting of components and finally cost efficiency. Also, the lower weight of the building with the CLT walls can result in smaller size of the foundation and again cost saving. 


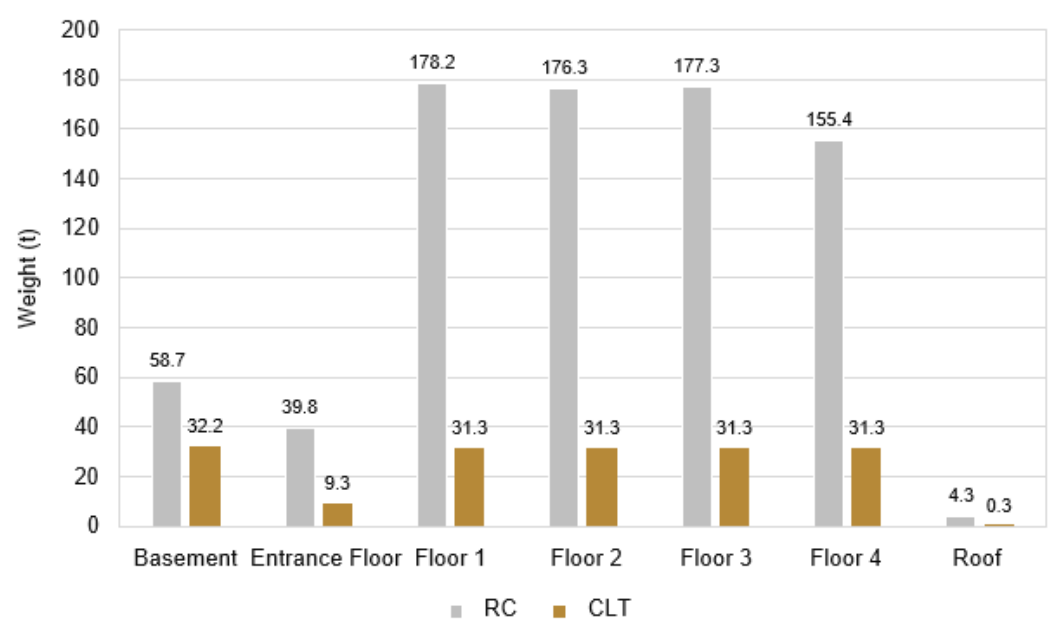

Fig.19. Comparison of weights of RC and CLT walls per floor.

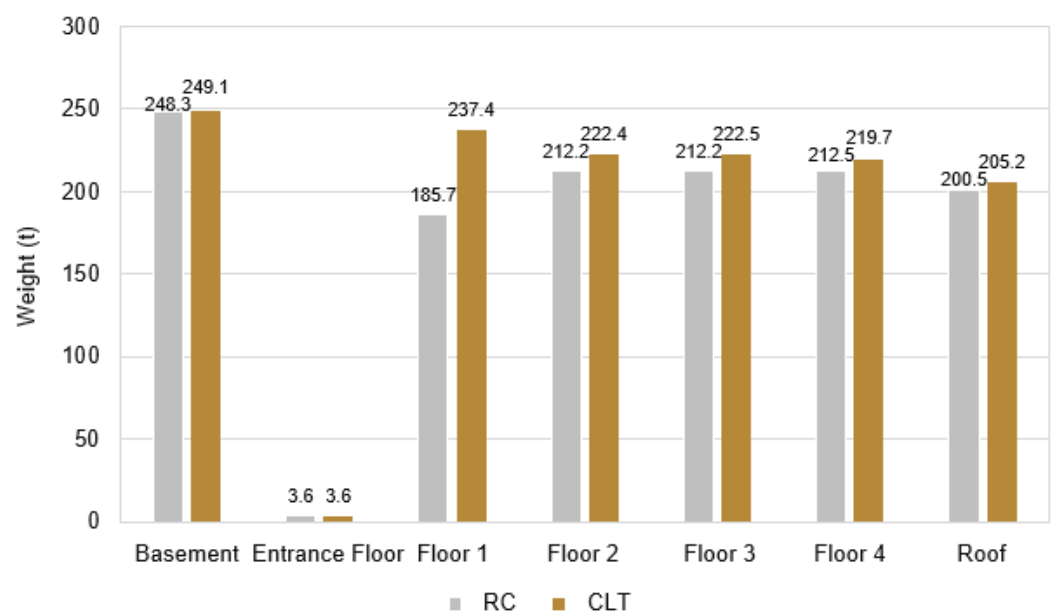

Fig.20. Comparison of total weights per floor considering slabs, beams and columns where the walls are made of RC or CLT.

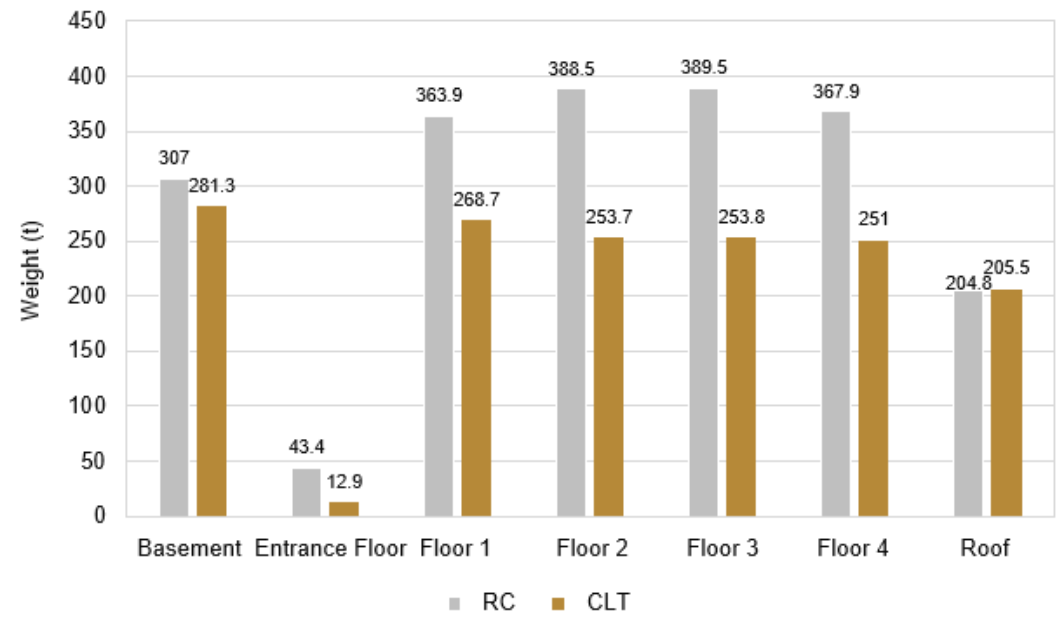

Fig.21. Comparison of total weights per floor considering walls, slabs, beams and columns where the walls are made of RC or CLT. 


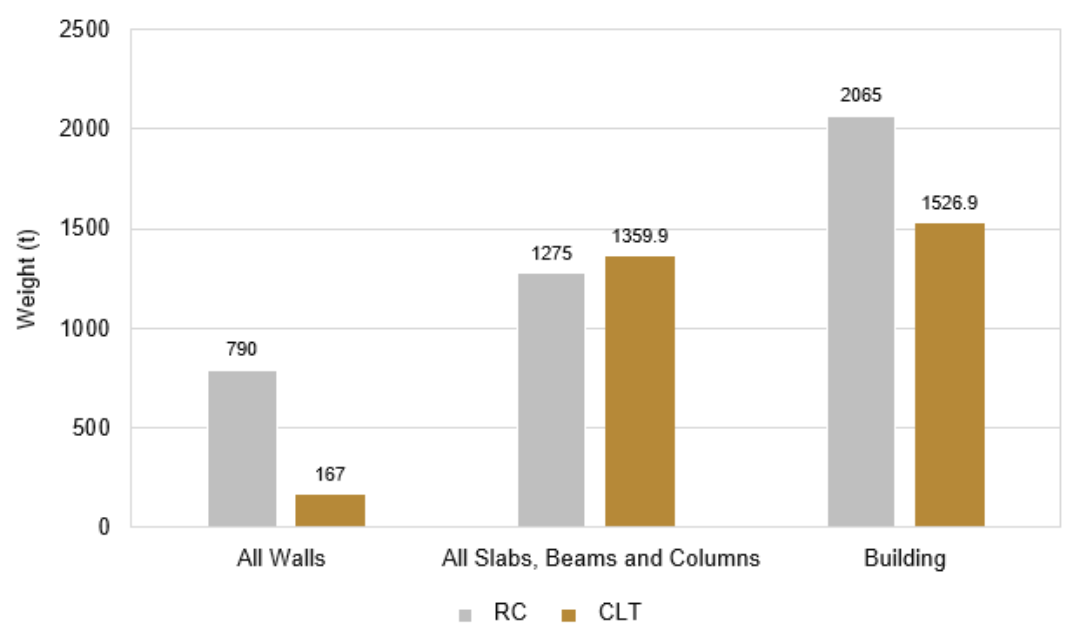

Fig.22. Comparison of total weights where walls are made of RC or CLT.

Moreover, the transportation of CLT components becomes more environmentally friendly and costeffective as the transport vehicles have limits on the maximum load weight they can take. In order not to exceed the loading weight, more transport vehicles may be needed when transporting RC components compared with CLT components, consequently, CLT can result in fewer transports and faster deliveries.

\section{Conclusions}

The CLT and RC walls were compared in terms of their performance. To investigate the walls, the FEM-Design software was utilised. An existing building was taken into consideration as the reference building. Once the building was considered to have RC walls and another time to have CLT walls. Both buildings were modelled, analysed and designed. The obtained results were compared from the utilisation ratio and weight viewpoints. The exterior CLT walls required larger thicknesses than the exterior RC walls to accomplish the acceptable utilisation ratio. Also, the utilisation ratios of most of the CLT walls were found to be lower than the RC walls. The slabs, beams and columns made of RC in both buildings having RC or CLT walls required to have a greater amount of reinforcement, however, their utilisation ratios were lower when the CLT walls were used. The entire building having the CLT walls was lighter than the building having the RC walls, implying 26\% lower weight. Whilst, the weight of the CLT walls was $21 \%$ of the weight of the RC walls which could lead to constructing safer, lifting components easier, having lighter foundation and finally saving cost. In addition, CLT components could be transported in a more environmentally friendly and cost-effective condition than RC components.

\section{Nomenclature}

$$
\begin{aligned}
C L T & - \text { cross-laminated timber } \\
R C & - \text { reinforced concrete } \\
\text { FEM-Design } & - \text { StruSoft FEM-Design } \\
E K S & - \text { Swedish national annex } \\
3 D & - \text { three-dimensional }
\end{aligned}
$$

\section{References}

[1] Bajzecerová V. (2017): Bending stiffness of CLT-concrete composite members - comparison of simplified calculation methods.- Procedia Engineering, vol.190, pp.15-20. 
[2] Van De Kuilen J.W.G., Ceccotti A., Xia Z. and He M. (2011): Very tall wooden buildings with cross laminated timber.- Procedia Engineering, vol.14, pp.1621-1628.

[3] Vessby J., Enquist B., Petersson H. and Alsmarker T. (2009): Experimental study of cross-laminated timber wall panels.- European Journal of Wood and Wood Products, vol.67, pp.211-218.

[4] Saavedra Flores E.I., Ajaj R.M., Dayyani I., Chandra Y. and Das R. (2016): Multi-scale model updating for the mechanical properties of cross-laminated timber.- Computers and Structures, vol.177, pp.83-90.

[5] Oh J-K., Hong J-P., Kim C-K., Pang S-J., Lee S-J. and Lee J-J. (2017): Shear behavior of cross-laminated timber wall consisting of small panels.- Journal of Wood Science, vol.63, pp.45-55.

[6] Wadi H., Amziane S. and Taazount M. (2018): The lateral load resistance of unclassified cross-laminated timber walls: Experimental tests and theoretical approach.- Engineering Structures, vol.166, pp.402-412.

[7] Shahnewaz Md., Alam Sh. and Tannert T. (2018): In-plane strength and stiffness of cross-laminated timber shear walls.- Buildings, vol.8, No.100, p.13.

[8] Hughes C., McPolin D., McGetrick P. and McCrum D. (2019): Behaviour of cross-laminated timber wall systems under monotonic lateral loading.- Journal of Structural Integrity and Maintenance, vol.4, No.3, pp.153-161.

[9] Pina J.C., Flores E.I.S. and Saavedra K. (2019): Numerical study on the elastic buckling of cross-laminated timber walls subject to compression.- Construction and Building Materials, vol.199, pp.82-91.

[10] Tuhkanen E. and Rauk L. (2019): Potential of cross-laminated timber for independent shear wall systems.- Wood Material Science and Engineering, vol.14, No.5, pp.355-365.

[11] Shahnewaza Md., Popovski M. and Tannert T. (2020): Deflection of cross-laminated timber shear walls for platform-type construction.- Engineering Structures, vol.221, Manuscript No.111091, https://doi.org/10.1016/j.engstruct.2020.111091.

[12] Stoner M. and Pang W. (2020): Simulated performance of cross-laminated timber residential structures subject to tornadoes.- Frontiers in Built Environment, vol.6, Manuscript No.88, https://doi.org/10.3389/fbuil.2020.00088.

[13] Chen Z. and Popovski M. (2020): Mechanics-based analytical models for balloon-type cross-laminated timber (CLT) shear walls under lateral loads.- Engineering Structures, vol.208, Manuscript No.109916, https://doi.org/10.1016/j.engstruct.2019.109916.

[14] Aloisio A. and Fragiacomo M. (2021): Reliability-based overstrength factors of cross-laminated timber shear walls for seismic design.- $\quad$ Engineering Structures, vol.228, Manuscript No.111547, https://doi.org/10.1016/j.engstruct.2020.111547.

Received: February 14, 2021

Revised: July 27, 2021 